\title{
THE EFFECTIVENESS OF SOCIAL RIGHTS IN PUBLIC HEALTH
}

\author{
CARLOS NETO, Daniel ${ }^{1}$ \\ DENDASCK, Carla ${ }^{2}$ \\ OLIVEIRA, Euzébio de ${ }^{3}$
}

CARLOS NETO, Daniel; DENDASCK, Carla; OLIVEIRA, Euzébio de. The effectiveness of social rights in public health. Multidisciplinary Core Scientific knowledge Magazine - Vol. 1. Year. 1. March. 2016, pp: 3-14 ISSN:0959-2448

\section{SUMMARY}

The fundamental rights have been cause for various discussions in recent years, causing scholars to dedicate themselves to investigate both through the health aspect, as through the law, the actual effectiveness of the guidelines outlined by the Organizations. This article aims to bring a brief reflection about the real effectiveness of social rights in the brazilian public health, using as a basis, an exploratory analysis of the elucidações brought by various scholars that permeate to corroborate this. Bringing a brief discussion of the existential minimum.

\footnotetext{
${ }^{1}$ Lawyer. Of academic medicine. $\mathrm{PhD}$ in public health. Executive Mba. Specialized in Applied health services. Graduation in family health. Audit specialist. Email: autor@nucleodoconhecimento.com.br

2 Doctorate in Psychoanalysis, post doctoral candidate in Clinical Psychoanalysis, and master in Bioethics, Director of the Center for research and development of advanced studies, Coach, and teacher of MBA courses in company, Campinas and São Pauloemail: autor@nucleodoconhecimento.com.br

${ }^{3}$ Biologist. Master in biology. Doctor of medicine/Tropical Diseases. Researcher of the Graduate program of the Center for Tropical Medicine of the UFPA. Professor in graduate level and post-graduate and researcher at the Federal University of Pará UFPA. Email: autor@nucleodoconhecimento.com.br
} 
KeyWords: Social Rights. Public Health. Effectiveness of fundamental rights.

\section{INTRODUCTION}

Fundamental rights can be defined as a set of rules, principles, rights, duties and institutes involved in popular sovereignty, that guarantee the peaceful coexistence, free and equal, regardless of creed, race, origin, colour, social status or economic condition, all based on the principle of human dignity. (BLOOD CELLS, 2010)

However, to José Afonso da Silva, if conceptualizing fundamental rights becomes a difficult task before the various transformations over time, see:

The expansion and transformation of fundamental human rights in history involved makes it difficult to set them a synthetic concept.

It increases this difficulty the circumstance to employ various expressions to designate them, such as: natural rights, human rights, human rights, individual rights, public subjective rights, fundamental freedoms, civil liberties and fundamental rights and fundamental human rights. (SILVA, 2005, p. 179)

Already social rights, are fundamental rights of man, as is formulating Moraes (2014, p. 595):

Social rights are fundamental rights of man, because they relate to a complex of social, economic or cultural relations that develops for realization of life in all its potential, without which the holder could not reach and enjoy the goods you need.

It turns out that the main difficulty to be faced in this topic refers to the applicability and effectiveness of these rights, because as we all know, health is positivada in the list of social rights.

Thus, it is important here to mention the concept of the term ' effectiveness ' as the concrete performance of the social function of law, as follows: 
The notion of effectiveness, namely, that specifies effectiveness, corresponds to that Kelsen-distinguishing the concept of effectiveness of the standard-portrayed as being "the actual fact of her being effectively implemented and observed, the fact that a human conduct as the standard to verify the facts". Effectiveness means the realization of the right, the performance of its social function. She represents the materialization, in the world of facts, the legal precepts and symbolizes the rapprochement, as close as possible, between the normative and should be be of social reality. (BARROSO, 2002, p. 236)

About the effectiveness of social rights is necessary to the understanding not only of the rule of law in a broad sense, but the same approach with other systems, such as: political, economic, social and historical.

It is necessary also the duration and effectiveness of the standard, as follows:

The normativismo distinguishes, with precision, the duration of effectiveness. The lesson of Kelsen is quite clear in this respect. The duration of the standard, to him, belongs to the must-be, and not to the order of being. Term means the existence specifies the standard; effectiveness is the fact that the standard is effectively applied and followed; the circumstance that a human conduct as the standard applies to the facts. (SILVA, 2005, p. 64)

One of the most relevant issues surrounding the effectiveness of fundamental social rights with respect to the way they were arranged in the constitutional text, considered by many authors and even methodologically inadequate. In this sense, it is stated that:

Fundamental social rights in the Brazilian Constitution are far from forming a homogenous group, because, with regard to its content and the way of its recognition, the constituent Assembly did not follow constituted no rows or theory specifies. Instead, ended up creating a chapter very contradictory regarding internal relationship of rights and guarantees. This, no doubt, entails a number of interpretative drawbacks, directly affecting the effectiveness of the provisions contained in the Constitution. (KRELL, 2002, p. 21) 
Although, there is this confusion, for Ana Paula de Barcellos, the legal effectiveness of the standard is directly linked with the social fundamentalidade, as stated below:

The first criteria that guides the identification of modalities of legal effectiveness the regulatory statements concerning you can style of social condition fundamentalidade for he governed, which is your level of importance or social relevance. This is the logical parameter that drives the legislative policy in General. The more fundamental to society is matter disciplined by the device and, therefore, the effects that he intends to be produced, more consistent must be the legal efficacy associated (...). (BARCELLOS, 2002, p. 136)

By legal effectiveness, understands "ability (potential) of a constitutional standard to produce legal effects". (KRELL 2002, p. 39).

To produce the desired legal effects, the legal effectiveness of social rights, are in full effectiveness standards subdivide, effectively contained and limited effectiveness, as explained below.

Full efficiency standards have immediate applicability, and thus are independent of subsequent legislation for its full implementation. It is stated that:

Are those that, since the entry into force of the Constitution, produce, or possibly produce all the essential effects, in relation to the interests, behaviors and situations, that the constituent legislator, direct and normatively, meant to regulate. (SILVA, 2005, p. 101)

Constitutional standards of effectiveness already contained are that have mandatory character, but are also limiting of public power, as it appears:

The efficiency standards contained are those that the constituent legislator regulated sufficiently the interests relating to a particular matter, but left room the restrictive part of the discretionary competence of the public authorities, in accordance with the law establishing or in terms of general concepts in it. (SILVA, 2005, p. 116) 
And last but not least, the limited effectiveness standards that rely on law to regulate them. Are called also "deferred application standards, standards of effectiveness and efficiency standards on immediate" (BLOOD CELLS, 2010, p. 146)

So you can see clearly that the applicability of social rights is identical to that of fundamental rights and guarantees. That is, have immediate applicability as has the $\S 1$ of art. 5 of $\mathrm{CF} / 1988$.

\section{THE ISSUE OF EFFECTIVENESS OF SOCIAL RIGHTS IN THE CONSTITUTION}

A lot of discussing on the doctrine about the effectiveness and on the applicability of constitutional rights. However, regardless of the form of recognition, the standards of fundamental rights must generate a minimum of legal effects, because as you've seen, all standard has effectiveness and applicability.

However, is the degree of effectiveness of fundamental social rights will be determined by the form of the Constitution and recognition of the peculiarities of your object. (SARLET, 2007, 237-238)

The biggest problem currently does not refer to the rights, but about the lack of effectiveness of the constitutional rules, see:

The fundamental problem in relation to human rights, today, is not so much to justify them, but to protect them (...). It is not a question of knowing what and how are these rights, which nature and its Foundation, whether they are natural or historic rights, absolute or relative, but what is the safest way to guarantee them, to prevent, despite the solemn declarations they are continually violated (BOBBIO, 1992, p. 24-25)

In this way, the reduced effectiveness of the fundamental social rights not only the absence of ordinary laws.

The bigger problem is not the provision of basic social services by the Government, since the vast majority of standards for the exercise of social rights already exists. See 
if the problem is in the "formulation, implementation and maintenance of their public policies and in the composition of spending in the budgets of the Union, the States and the municipalities". (KRELL, 2002, p. 31-32)

Another problem that discusses on doctrine is on the determination of the elements constituting fundamental social rights that connects to the fact these rights only exist "when the laws and social policies the guarantee. In other words: it is the ordinary legislature which creates and determines the content of a social right "(CANOTILHO, 2002, p. 481).

This substantial part of the doctrine considers most of the constitutional provisions concerning social rights "as unable to present any other legal effectiveness in addition to bind negatively the legislature from acting explicitly against the objective indicated by the standard". (BARCELLOS, 2002, p. 162)

That said, it appears that much of the doctrine usually classify defining standards of social rights as programmatic standards, since they require a legislative achievement that may generate the fullness of its effects.

In this sense, it is stated that programmatic standards are:

Those in the legislature, constituent or not, instead of editing legal rule of practical application, only traces lines directors, which will guide the public authorities. The legislation, the implementation and the Justice shall be subject to these dictates, which are like programs data to your function (BARROSO, 2002, p. 115)

Still, according to Krell (2002, p. 27-28), the programmatic standards serve as an alibi to create an image that the State responds, normatively, the problems of society, see:

Many programmatic social rights constitutional standards, for not having a minimum of conditions for its implementation, serve only an alibi to create the image of a State that responds normatively the real problems of society, playing a mainly ideological function in constitute a form of manipulation or illusion that immunizes the political system against other alternatives. 
However, this does not seem to be the current trend of effectiveness of social rights, as against those arguments, just reveal the danger if you leave the will of the legislator or the administrator determining total social effects of fundamental rights.

As States Barcellos (2002, p. 192): "this could cause a real empty the fundamentabilidade of the principle of dignity of the human person as a vector in constitutional interpretation."

It should be stressed here, that the situation becomes more complicated where the Government keeps inert, i.e. where not yet installed the necessary services or where work poorly.

The positive benefits of social rights should be provided by the State and supported by society, who will bear these costs, collected through taxes among others as supported:

Definitely there are resources, the more clear and precise textual forms will not be able to overcome this factual reality, will be unworkable rules. Luís Roberto Barroso already identify this situation, in which the apparent absence of material conditions condemns the standard since its inception, as a form of insincerity. What if you want to emphasize, therefore, is that by taking care of the interpretation of public law in General, and of the particular constitutional, it is necessary to have in mind, in addition to the purely legal elements, data of reality, one of them being the material conditions and achieve the financial regulatory controls. (BARCELLOS, 2002, p. 259-260)

However, before the malfunction or even lack of services essential to the well-being of the population, the "formulation of public policies protective of certain social categories economically marginalised and excluded", these policies that demand mainly state management, being of paramount importance for its implementation, partnerships with civil society. (KRELL, 2002, p. 34)

Soon, the derived rights to benefits, arising from social rights regulations laid down in the Constitution, imply, where already deployed the public service necessary for satisfaction of a Fundamental right, that its not provision in violation of ordinary law 
can, in Brazil, be attacked by means of injunction, effective legal instrument on judicial control of administrative acts.

Thus, it is stated that:

The effectiveness which must accompany the rules of fundamental social rights especially when founded on the dignity of the human person - must be positive or symmetrical, because it enables the judiciary, if there is a violation to unconstitutional, execution of law. The modalities of interpretative and vedativas negative effectiveness of reverse, although absolutely relevant and current, are insufficient protection of certain factual variables arising from the imperative of respect for the essential core of social rights. (BARKER, 2011, p. 102-103)

For this reason, to tackle the problems of effectiveness of social fundamental rights, there is no way to disregard their primary function the provision rights, as well as its recognition in the constitutional text, since both aspects, all evidence, constitute factors closely linked to the degree of effectiveness and applicability of fundamental rights, as already mentioned.

Another issue that undermines the effectiveness of fundamental rights is the so-called ' possible ' reserve, which has been used to indicate the limitation of resources before the need for the guarantee of fundamental and social rights. As demonstrates Barcellos (2002, p. 261):

The debate on this issue has been identified in Brazil through the reservation possible expression and popularized largely by the Government's commitment to promote it and argues it in the most diverse demands, on the pretext of imminent economic Apocalypse always.

It turns out that the shortage of budgetary resources cannot be obstacles for the guarantee of social rights, which are essential conditions of human life, because in this way, ultimately violating basic and fundamental precept of the Federal Constitution: the principle of human dignity. 
In this way, to guarantee the minimum existential is necessary requirement for the survival of the individual, because if you do not have the conditions necessary for a dignified life, the social features are not being effective. And when it comes to existential minimum intended for health, violates the right to life, because without health you can't live.

\section{THE PRINCIPLE OF RESERVATION POSSIBLE}

You have no doubt that the legal guarantee of social rights does not depend on only positive benefits from the State, because their effectiveness depends on State resources (Union, State, Federal District and Municipalities), but these are limited. For this reason, the effectiveness of these rights is limited to the budgetary resources available. As per Sarlet and boss (2007, p. 265):

The placement of social rights to benefits under what is called a possible reserve that, understood in a broad sense, covering both the possibility, as the power of disposition on the part of the recipient of the standard.

To digress on the subject, it is necessary first to conceptualize the possible reserve Note:

The term reservation possible attempts to identify the economic phenomenon of the limitation of resources available on the necessity almost always infinite to be met by them. What matters to the study undertaken here, the possible means that, in addition to the legal discussions about what can be expected in court in the State - and last review of society, for it is this that sustains - it is important to remember that there is a limit of material possibilities for these rights. (BARCELLOS, 2002, p. 261-262)

This question about the effective availability of funds is seen by the doctrine as a factual limitation to the effectiveness of social rights. However, there is also another limitation that is about the legal possibility for the disposition of resources.

On the subject, said Barcellos (2002, p. 262-263): 
Under the general title of the reserve can live at least two different species of phenomena. The first of these deals with the absence of factual resources, something close to the budget, and exhaustion can be identified as a reserve of possible factual. It is possible to question the reality of this kind of circumstance when it comes to public authorities, having regard to the form of fundraising and the nature of the tickets. Anyway, the lack of resources would describe situations about which one might speak of possible factual reserved.

The second phenomenon identifies a possible legal reserve since it doesn't describe exactly a State of exhaustion of resources, and the absence of budget authorization for certain spending in particular.

Soon, the beginning of the reserve is a factual and legal limitation that the State goes for help provide social rights to whom it may concern. This is the big problem here raised, because it refers to multiple claim by the Government of this principle, only to avoid the obligation of implementation of fundamental rights.

In relation to such a problem is stated:

The Brazil has one of the worst pictures of income distribution in the world, and condition the realization of economic, social and cultural rights to the existence of available resources in the State, means reducing its effectiveness to zero, put their universality, condemning them to consider minor rights (KRELL, 2002, p. 54)

That is, the majority of the Brazilian population that is poor, i.e., deficient in social services is who else suffers from this clash of be have the execution of rights based on the availability of public resources.

Therefore, although the effectiveness of social rights depend on the consideration of the Government in their choices in the face of resource scarcity, the same can not shirk its constitutional duty to provide and ensure minimum rights to the population for a life with dignity, and in the absence of any of them, it is up to the judiciary, through provocation settling any problem on the subject and that has occurred with the frequency that shows the problem analysis. 


\section{FINAL CONSIDERATIONS}

Assuming that the population's needs are endless and limited resources, it should be kept in mind about how to establish priorities in the allocation of resources to ensure the minimum established in the Federal Constitution.

First, point out that the formulation of the minimum existential concept originated in the German Constitutional Court, which drew the right to a minimum of existence of the principle of human dignity (Constitution, art. 1, I) and of the right to life and physical integrity, through systematic interpretation by the principle of the Social State (LF, art. 20, I) (KRELL .2002).

Complementing the understanding:

At first, the qualification, qualification of human dignity as a fundamental principle expressing the certainty that art. 1st, Inc. III, of our basic law does not contain only a statement of ethical and moral content (which she, but in the final analysis, it does have), but that constitutes legal standard-positive with constitutional status and, as such, with effectiveness, turning such lucky, beyond the ethical dimension already pointed, in legal value of community. In this context, need to be considered, provided that fundamental principle, the dignity of the human person is not only guide value of fundamental rights, but of the whole constitutional order, which fully justifies its characterization as a constitutional principle of greater axiological hierarchyevaluative. (SARLET, 2007, p. 111-112)

That is, the existential minimum is linked to the dignity of the human person and must be guarded by the features social rights in order to provide minimum conditions of the population.

In an attempt to delimit the contents of the existential minimum, a possible solution is the use of the principle of dignity of the human person to ensure the minimum conditions of the population for a healthy life ", suggesting how minimum guideline parameters established by the World Health Organization. (SARLET, 2006, p. 47-59) 
Yet there are still large room for a legislator's policy, since there is no "one right measure or a unique way of compliance with the constitutional imperative", IE: there is a fixed content of the right to a decent existence mínimopara, which can only be defined in the specific case. (ANDRADE, 2002, p. 27)

Of all sorts, the default minimum for survival should always include a basic and efficient health care, access to basic food and clothing, the education of the first degree and the guarantee of a dwelling, as below:

Now, if the company is not able to recognize at what point people find themselves in a situation unworthy, i.e. If there is no consensus regarding the minimum content of dignity, "will be facing an ethical and moral crisis of such proportions that the principle of human dignity will be transformed into a totally empty formula" (BARCELLOS , 2002, p. 197)

Soon, the guaranteed social minimum in the material conditions of existence would be based on the concept of human dignity, and the rhetoric of this depreciaria minimum social rights, but rather, would strengthen in their essential dimension as an expression of vindicatory citizenship.

Constitutionally guaranteed, the existential minimum must be serviced as a priority, says Barcellos (2002, p. 268):

If that's so, and means the financial resources are not unlimited, the available resources should be applied as a priority in the service of the purposes considered essential by the Constitution until they are achieved.

The remaining resources will be designed according to the political choices that democratic deliberation to establish in every moment.

Whereas the minimum existential, inherent constitutional guarantees priorities (basic rights features), has immediate applicability for being in fundamental rights regardless of whether or not social. On the other hand, as the supply is not dealing with social 
rights linked to the existential minimum, will be conditioned the limitations of budgetary resources.

However, it is the public authorities a duty to comply with what the Constitution guarantees as Krell (2002, p. 60):

Where the State creates these offerings for the collective, it must ensure the possibility of citizen participation. And if the legislation does not grant a right to express individual receiving vital services, the citizen can appeal to the fundamental right of equality in connection with the principle of the Social State

Once violated the existential minimum, by the omission of the effectiveness of the fundamental social rights, the right to demand in court.

The reason that justifies such judicialisation of social rights, inherent to the existential minimum, by virtue of which such rights are indispensable to have a life with dignity, which is the theory of the reserve can not submit here. Though judicialisation trying to decrease this problem of lack of resources, you have to have a view on which the essential purpose laid down in the Constitution, and whether the resources are sufficient to meet the intended purpose. (BARKER, 2011).

But is faced with the existential minimum that will evaluate priorities for public spending, based on the Constitution, and also can define the jurisdictional activities of social rights

According to Canotilho (2002), the State should ensure the effectiveness of social rights as you already know, but it is worth saying, too, that the same cannot reduce, cancel or revoke what today we understand as existential minimum and shall seal all the legislative measures aimed at this. This is the principle of prohibition of the social backlash.

Conceptualizing-if the reverse says: 
The reverse, finally, is a derivation of the negative effectiveness, particularly linked to the principles that involve fundamental rights. She assumes that these principles are implemented through infra-constitutional standards and that, based on the constitutional law in force, a general effects intended by such principles is the progressive expansion of fundamental rights. Starting from these assumptions, that the reverse can require the judiciary proposes is the invalidity the revocation of standard that, by regulating the principle, to grant or extend fundamental rights, without which the revocation in question is accompanied by a substitute or equivalent policy. (BARROSO, 2002, p. 379)

It is therefore concluded that this seal is a way to prevent the repeal of laws which ensure social rights, not to diminish what was achieved through the historical evolution, such as the establishment of minimum standards in order to have a life with dignity.

In this way, the role of the Judiciary in matters of social rights is important because it is the fundamental social rights control, analyzing the essentiality of the claim and the degree of need according to each individual case. And that these social rights judicialization, and especially health, object of the present study, is being called the judicialisation of health phenomenon.

\section{BIBLIOGRAPHICAL REFERENCES}

ALMA-ATA. Alma Ata. 1978. Available at: http://www.saudepublica.web.pt/05promocaosaude/Dec_Alma-Ata.htm. Access in: 09 nov. 2015.

ANDRADE, José Carlos Vieira de. The judiciary and Fundamental Social rights: access to health, question controversy. Porto Alegre: Court of Justice, 2002.

BARCELLOS, Emanuel. The Legal Effectiveness of the Constitutional Principles: the principle of human dignity. Rio de Janeiro: Renovar, 2002.

BARROSO, Luís Roberto. The constitutional law and the effectiveness of its rules: limits and possibilities of the Brazilian Constitution. 6 ed. São Paulo: Renew, 2002 
BARKER, Ramon F. Judicialization of the right to health: the tension between the "existential minimum" and the "possible reserve" in the search for the preservation of human dignity. Curitiba: Juruá Editora, 2011.

Brazil. Constitution (1988). Constitution of the Federative Republic of Brazil. Brasilia. DF: Senate, 2014.

Brazil. Law No. 8,080 of September 19, 1990. Rules on the conditions for the promotion, protection and recovery of health, organisation and functioning of the corresponding services and other matters. Diário Oficial da União, Executive Branch, Brasília, DF.

BLOOD CELLS, Uadi Lammego. Constitutional law within everyone's reach. 2nd ed. São Paulo: Saraiva, 2010.

CANOTILHO, José Joaquim Gomes. Constitutional law and Theory of the Constitution. 6. ed. Coimbra: Almedina, 2002.

KRELL, Andrea Joachim. Social rights and Judicial Control in Brazil and in Germany: the $(U N)$ paths from a comparative constitutional law. Porto Alegre: Sergio Antonio Fabris, 2002

Moraes, Guilherme pity. Constitutional law course. São Paulo: Atlas, 2014.

SARLET, Ingo Wolfgang. The effectiveness of fundamental rights. 7. Ed. Porto Alegre: Editora Lawyer, 2007.

Human dignity and fundamental rights in the Federal Constitution of 1988. 4 ed. Porto Alegre: Editora Lawyer, 2006.

SILVA, José Afonso da. Contextual commentary on the Constitution. São Paulo: Malheiros, 2005. 